\title{
A Case of Chancre of the Cervix Uteri.
}

\author{
By Frances Ivens, M.B., M.S. (London), \\ Gyncecologist, Stanley Hospital, Liverpool.
}

Mrs. G., a married woman, at. 32, came to the Out-patient department at the Liverpool Stanley Hospital, on September 14th, 1907, complaining of backache. Of four children, the oldest had died of " consumption of the bowels," the second was still-born, the two others were healthy, the youngest being 15 months old.

The patient had enjoyed good health until 3 months previously, when she consulted a doctor for backache, and had a Hodge pessary inserted. For a few weeks micturition had been frequent and painful, and she had noticed blood in the urine. Her husband had recently been under treatment for three weeks for "discharge."

On examination a blood-stained purulent urethral discharge could be seen. There was no ulceration of the vulva, and no enlargement of the glands in the groin. The uterus was lying back, and was freely movable. The external os was rather patulous, and on the portio vaginalis slightly to the right side and extending on to both lips was an ulcer the size of a shilling. The surface was covered by a greyish slough, and the base was indurated. On wiping the surface blood oozed freely.

In the urethra, near the neck of the bladder, was a linear ulcer, and the mucous membrane was intensely congested.

I concluded the urethral condition was of gonorrhoeal origin, but I regret that no bacteriological examination was made at the time. With regard to the cause of the ulceration of the cervix, the induration and situation suggested malignancy, though the patient was rather young, but the unusual character of the ulcer and the associated gonorrhoea pointed to the diagnosis of a syphilitic lesion. To make certain I excised a small wedge from the edge of the ulcer for microscopical examination, from which I have had a drawing prepared. The section shows inflammatory changes only. The healthy epithelium ends abruptly, and the surface of the ulcer consists of exudation and necrotic granulation tissue. The connective tissue, hyperæmic and densely infiltrated with round cells, shows extreme cellular proliferation.

The intima of the vessels is thickened.

While waiting for secondary symptoms to develop antiseptic vaginal douches were given. 
On October 23rd, five weeks after the patient first came up, she complained of sore-throat, and characteristic superficial ulceration was seen on the tonsils. The ulcer on the cervix had not diminished in size, but looked cleaner.

The patient was then put on a course of mercury, in the form of Hutchinson's pill, gr. xv. daily, and weak perchloride of mereury douches were given.

The throat condition cleared up in a few days, and in about three weeks the chancre had disappeared. On November 23rd a roseolous rash appeared on the lower limbs, and some condylomata near the anus. The urethritis yielded to local applications of silver nitrate (gr. xxx. ad 3i). The patient now states that she feels perfectly well. She is still having mercurial treatment (January 24th, 1908).

I am recording this case as there is such diversity of opinion among gynæcologists regarding the incidence of chancre of the cervix, and its importance in the diagnosis of carcinoma of the portio vaginalis.

Sir W. Japp Sinclair ${ }^{1}$ states " My experience of English practice leads me to the conclusion that syphilitic ulceration of the vaginal portion of the uterus is among the rarest of the diseases of women. I have several times in the earlier years of special work suspected syphilis and temporised accordingly in order to see the effect of general and local treatment, but in not one single case has the ulceration turned out to be other than malignant."

Dr. McCann says" "A primary sore (of the cervix uteri) is not rare." This statement is criticised ${ }^{3}$ by the reviewer of his book "Cancer of the Womb," in the Lancet, October 12th, 1907, as being unsupported by proof.

Dr. Pernet, 4 in a letter to the Lancet, November 16th, 1907, supports Dr. McCann on the results of his own experience, and also quotes Fournier's statistics.

The latter writers says: "Le chancre du col passe pour une rareté pathologique. M. Clerc dans sa statistique n'en mentionne qu'un seul cas sur un total de 113 chancres du diverses régions. M. Carrier ne le cite pas dans la sienne. Les traités de gynécologie s'en préoccupent à peine et certains même le passent sous silence. Bref, de l'aveu général le chancre utérin serait une lésion véritablement exceptionelle. Je proteste energiquement pour ma part et contre ces statistiques et contre cette croyance commune. $\mathrm{Si}$ je consulte en effet mes souvenirs je suis bien certain d'avoir recontré le chancre utérin d'une façon assez fréquente. Et si je m'en rapporte à mes notes je trouve sur un total de 249 chancres génitaux, 13 cas de chancres du col." 


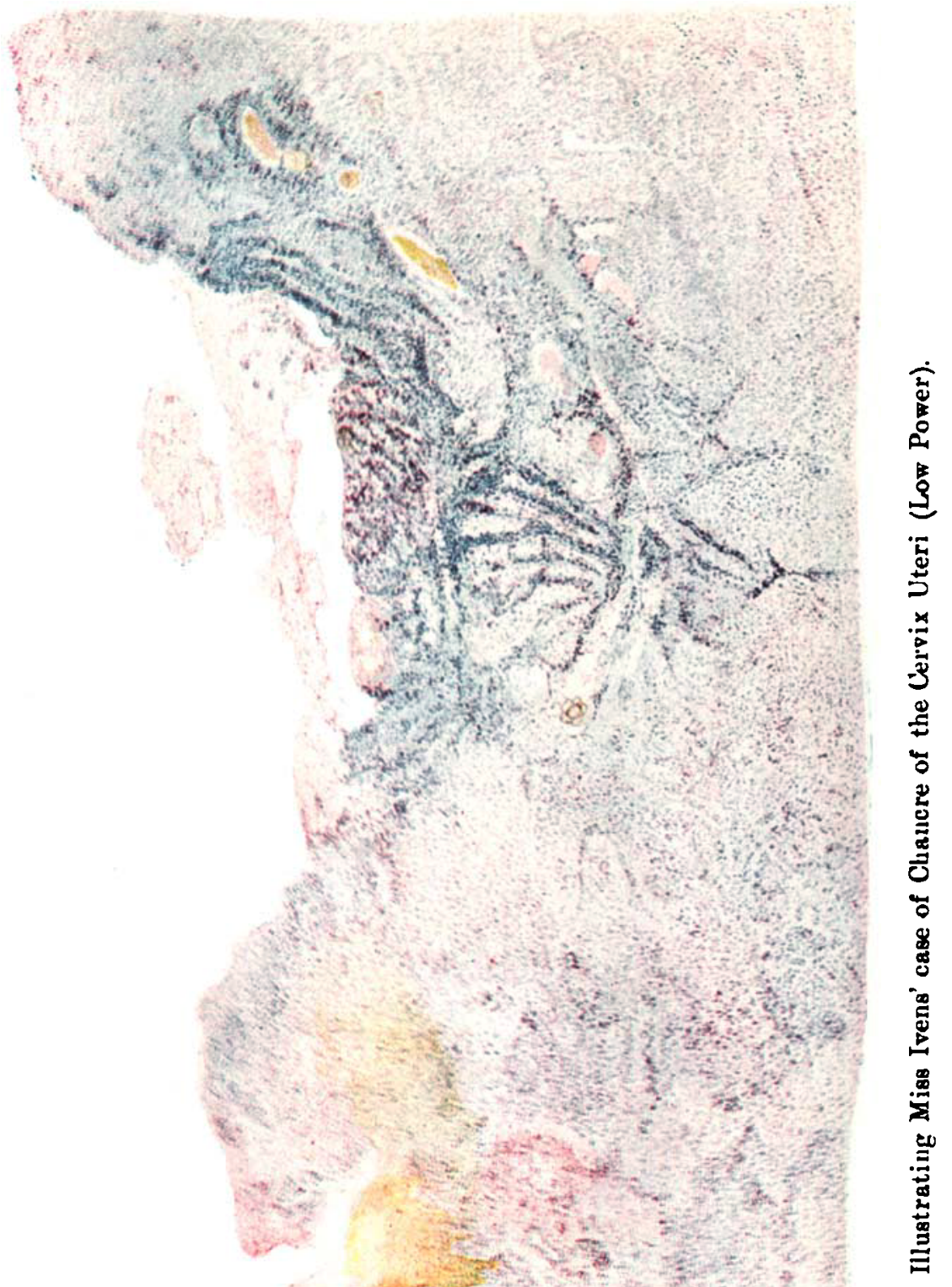


Dr. Herman ${ }^{6}$ gives the notes of a case which came under his observation when secondary lesions had already occurred. The physical characters of the ulcer appear to resemble closely those of the one I have described.

\section{Burrances.}

1. Sinclair (Sir W. Japp). Allbutt and Playfair's Gynacology, p. 346. London : Macmillan Co., 1906.

2. McCann. "Cancer of the Womb." London.

3. Lancet, October 12th, 1907, p. 1027.

4. Pernot. Lancet, November 16th, 1907, p. 1419.

5. Fournier. "Byphilis chez la Femme," 1881 ; second edition.

6. Herman. Obstet. Trans., vol. sxvii. 